\title{
今月の症例 44
}

\section{3 回の自家末梢血幹細胞移植 (peripheral blood stem cell transplantation ; PBSCT) 併用大量化学療法により 完全寛解を得た再発卵巣胚細胞腫瘍の 1 例}

\author{
東京都立駒込病院化学療法科 \\ 林千鶴子 小室泰司 岡元るみ子 \\ 小林健彦 前田義治 佐々木常雄 \\ 同 外科 \\ 西村嘉裕 \\ 同 輸血科 \\ 比留間潔
}

\begin{abstract}
【概要】 17 歳, 女性. 卵巣胎児性癌摘出術後, 不正性器出血, 下腹部腫瘤を主訴に来院。骨 盤内局所再発, 多発性肺転移と診断された. BEP療法を施行するも治療継続中に腫瘍マーカー の上昇を認めたためPBSCT併用大量化学療法を施行し，繰り返し行うことにより完全寛解 を得た.胚細胞腫瘍は抗癌凨に高い感受性を示すが, 治療抵抗性の場合でも大量化学療法を 繰り返すことにより，充分な治療効果が望める可能性が示唆された症例であった.
\end{abstract}

〔日内会誌 $91: 3500 \sim 3502 ， 2002$ ]

【Key words】再発卵巣胚細胞腫癔, PBSCT併用大量化学療法

\section{症 例}

患者は 17 歳, 女性. 主訴：不正性器出血, 下 腹部腫瘤，腹痛．既往歴：特記事項なL．家族 歴：父方祖父が肺癌で死亡. 現病歴：1996 年 7 月不正性器出血, 下腹部腫瘤, 腹痛を認め近医 を受診．右卵巣腫瘍の診断にて腫場摘出術を施 行し, 卵巣原発胚細胞腫瘍 (embryonal carcinoma）と診断される.1997 年 7 月腹腔内転移, 多発性肺転移にて再発し, 10 月上記主訴にて当 院婦人科を受診. 腫演マーカーはAFP : 4197.4 $\mathrm{ng} / \mathrm{ml}$, HCG : $140,000 \mathrm{mIU} / \mathrm{ml}$ と高值を示した。 性器出血の止血目的に子宮動脈塞栓術を施行後,
化学療法 (bleomycin, etoposide, cisplatin : BEP 療法) 5 回にて部分寞解となるも 1998 年 4 月腫 瘍マーカーの再上昇がみられたため, PBSCT 併用大量化学療法目的に当科転科となった。 入 院時現症：瘦せ型. 眼瞼 - 眼球結膜に㥧血・黄 㾝なし. 表在リンパ節触知せず. 胸部異常なし. 下腹部正中に手術瘕痕あり，腫瘤触知せず，四 肢異常なし.入院時検查 : WBC $2,900 / \mu \mathrm{l}, \mathrm{RBC}$ $3.96 \times 10^{6} / \mu \mathrm{l}, \mathrm{Hb} 12.5 \mathrm{~g} / \mathrm{dl}$, PLT $271 \times 10^{3} / \mu \mathrm{l}$, Retic $2 \%$, 生化学検査はLDH $249 I U / l$ の他は異常なし. 腫瘍マーカー：AFP 191.61ng/ml，HCG 2,486.0 $\mathrm{mIU} / \mathrm{ml}$. 図 1 に婦人科初診時の胸部X-P, 及び

[平成 13 年 11 月 13 日 第 495 回関東地方会推㡲]

Three times high-dose chemotherapy and peripheral blood stem cell transplantation rescue for patient with refractory ovarian germ cell tumor

Chizuko Hayashi, Yasushi Omuro, Rumiko Okamoto, Takehiko Kobayashi, Yoshiharu Maeda, Tsuneo Sasaki,

Yoshihiro Nishimura* and Kiyoshi Hiruma** : Departments of Chemotherapy, *Surgery and**Blood Transfusion,

Tokyo Metropolitan Komagome Hospital, Tokyo 



B

図 1.A：婦人科初診時胸部単純X線写真：右中葉 に $3 \mathrm{~cm}$, 左下葉に $6 \mathrm{~cm}, 2 \mathrm{~cm}$ の多発性肺転移を 認める.

B : 骨盤MRI : 傽胼直腸間に 9cmの腫昜を認める.

A

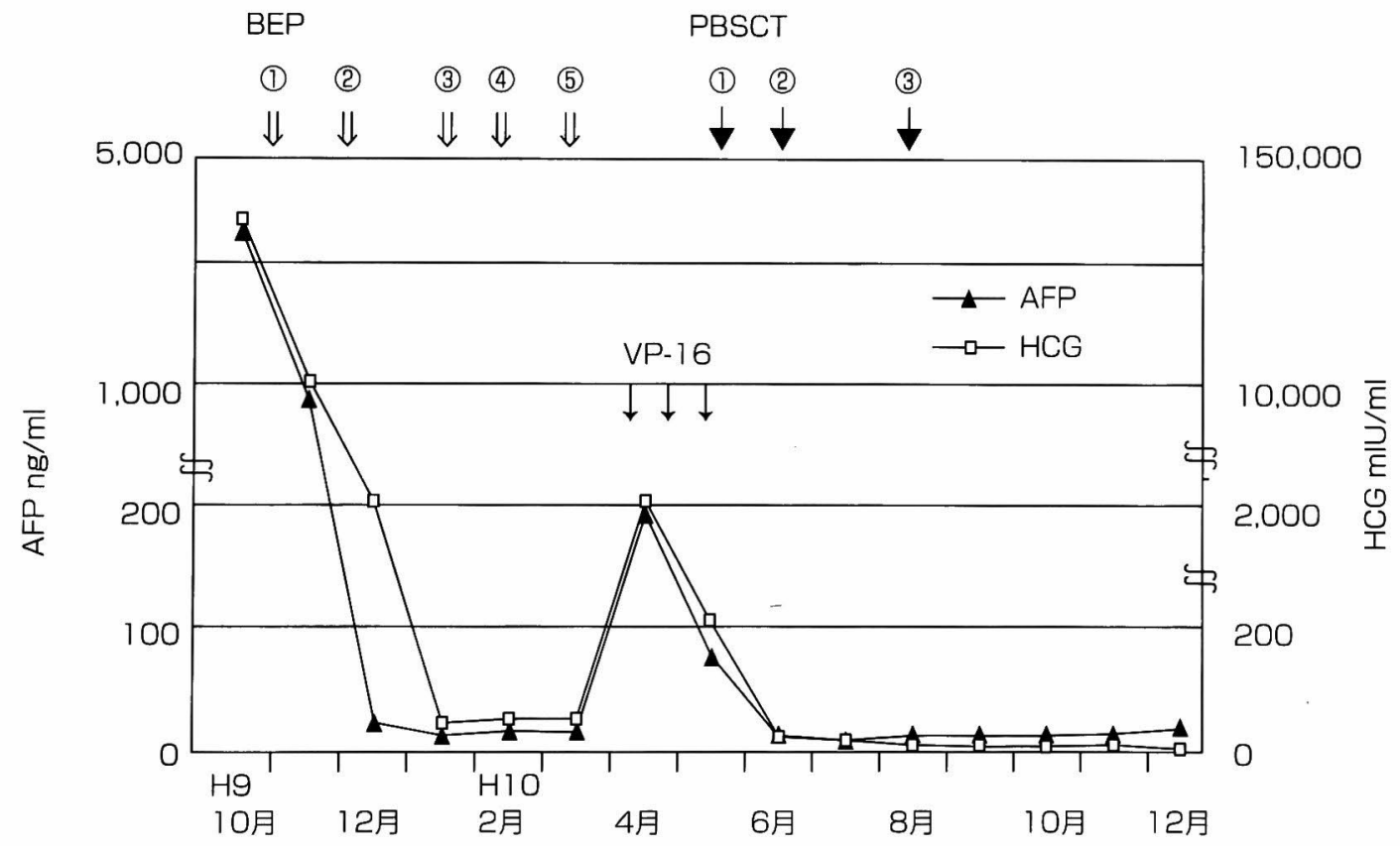

図 2.AFP・HCG值の推移

骨盤MRIを示す.この後bleomycin, etoposide, cisplatin (BEP) 療法が行われ部分寛解となった が腫瘍マーカーは陰性化せず再上昇した.

\section{臨床経過}

1998 年 4 月当科入院後etoposide $500 \mathrm{mg} / \mathrm{m}^{2} \times$
3 日投与後末梢血幹細胞を採取し, 5 月PBSCT 併用大量化学療法 1 回目 (carboplatin 200mg/ $\mathrm{m}^{2}$, etoposide $250 \mathrm{mg} / \mathrm{m}^{2}$, cyclophosphamide $1,200 \mathrm{mg} / \mathrm{m}^{2}$, dexamethasone $25 \mathrm{mg} / \mathrm{m}^{2}$ ) $\times 5$ 日を 施行. 胸・腹部CTではNCであったが, AFP 3.2 
$\mathrm{ng} / \mathrm{ml}, \mathrm{HCG} 2.4 \mathrm{mIU} / \mathrm{ml}$ と低下した. 6 月大量化 学療法 2 回目を施行し, 胸・腹部CTではNCで あったが腫煬マーカーはAFP $1.0 \mathrm{ng} / \mathrm{ml}, \mathrm{HCG}$ $1.0 \mathrm{mIU} / \mathrm{ml}$ と正常化した. 地固めのため 8 月大量 化学療法 3 回目を施行. 胸部CT : NC(腫瘍は縮 小するも残存). 腹部CT : NC, AFP · HCGは正 常値のままであった，その後無治療にて経過し たが腫瘍マーカーの上昇は認めず腫湯も残存し た. 1999 年 8 月肺の残存病変に対し胸腔鏡下左 肺下葉部分切除術を施行. 切除標本にviableな腫 瘍細胞を認めず組織学的に完全寛解を得た．以 後外来通院にて経過観察中であるが, 2001 年 11 月の時点で再発を認めずCRを継続している.

\section{考 察}

胚細胞腫瘍は，抗癌削・放射線照射に高い感 受性を示すことが知られている。再発，進行胚 細胞腫瘍, 性腺原発非セミノーマに対する標準 的治療はcisplatinを含む多剂併用化学療法であ り，代表的なものはBEP療法 (bleomycin, etoposide, cisplatin) である1). BEP療法は胚細胞腫 瘍に対し奏効率 $83 \%$, 完全寛解率 $77 \%$ と優れた 治療効果を表す2.3). これらの化学療法にても AFP・HCGが正常化しないような治療抵抗性, あるいは再発症例のような予後不良群に対して のsalvage chemotherapyとしてPBSCTを併用し た大量化学療法 (carboplatin, etoposide, cyclophosphamide）が行われ，26〜 40\%の完全寛解 率が報告されている4 8). 今回の症例は, 標準的 治療に抵抗性の再発卵巣胚細胞腫瘍 (embryonal carcinoma)であり,一回目の大量化学療法にて 部分寞解となったもののAFP・HCGが正常化し なかったため 3 回繰り返し施行し, 経過中重症 感染症などの合併症を起こすことなく組織学的 完全宽解を得ることが出来た．現在のところ難
治性胚細胞腫瘍に対し大量化学療法を繰り返し 行うことについてはコンセンサスが得られてい ないが，治療抵抗性の胚細胞腫瘍にも優れた効 果を示す可能性があると考えられる.

\section{文献}

1) Motzer RJ, et al: Phase III Randomized Study of Bleomycin, Etoposide, and Cisplatin (BEP) With or Without High-Dose Carboplatin. Etoposide, and Cyclophosphamide Plus Autologous Bone Marrow or Peripheral Blood Stem Cell Transplantation in Male Patients With Previously Untreated Poor-or Intermediate-Risk Germ Cell Tumors, (Summary Last Modified 07/2001). MSKCC-94076, clinical trial, active, 09/08/1994.

2) Williams SD, et al : Treatment of disseminated germ-cell tumors with cisplatin, bleomycin, and either vinblastine or etoposide. New England Journal of Medicine 316(23) : 1435-1440, 1987.

3) Bosl GJ, et al:VAB-6 : an effective chemotherapy regimen for patients with germ-cell tumors. Journal of Clinical Oncology 4(10) : 1493-1499, 1986.

4) Saxman SB, et al:Salvage chemotherapy in patients with extragonadal nonseminomatous germ cell tumors. Journal of Clinical Oncology 12 (7) : 1390-1393, 1994.

5) Beyer J, et al: High-dose chemotherapy as salvage treatment in germ cell tumors: a multivariate analysis of prognostic variables Journal of Clinical Oncology 14(10): 2638-2645, 1996.

6) Loehrer PJ Sr, et al : Vinblastine plus ifosfamide plus cisplatin as initial salvage therapy in recurrent germ cell tumor. Journal of Clinical Oncology 16 (7) : 2500-2504, 1998.

7) Motzer RJ, et al: High-dose chemotherapy and autologous bone marrow rescue for patients with refractory germ cell tumor : early intervention is better tolerated. Cancer 69:550, 1992.

8) Siegert $W$, et al : Hight dose treatment with carboplatin, etoposide, and ifosfamide followed by autologous stemcell transplantation in relapsed or refractory germ cell cancer : a phase I/II study. Journal of Clinical Oncology $12: 1223,1994$. 